$1-1-1993$

\title{
Popular Sovereignty, Vigilantism and the Constitutional Right of Revolution
}

Christian G. Fritz

University of New Mexico - School of Law

Follow this and additional works at: https://digitalrepository.unm.edu/law_facultyscholarship

Part of the Law Commons

\section{Recommended Citation}

Christian G. Fritz, Popular Sovereignty, Vigilantism and the Constitutional Right of Revolution, 63 Pacific Historical Review 39 (1993).

Available at: https://digitalrepository.unm.edu/law_facultyscholarship/179

This Article is brought to you for free and open access by the UNM School of Law at UNM Digital Repository. It has been accepted for inclusion in Faculty Scholarship by an authorized administrator of UNM Digital Repository. For more information, please contact amywinter@unm.edu, Isloane@salud.unm.edu, sarahrk@unm.edu.

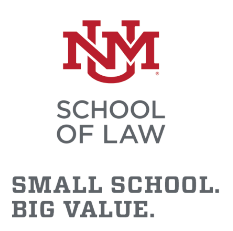

BIG VALUE. 


\title{
Popular Sovereignty, Vigilantism, and the Constitutional Right of Revolution
}

\author{
CHRISTIAN G. FRITZ \\ The author is a member of the school of law in the \\ University of New Mexico.
}

The focus of this article is the interplay of an indigenous American idea-popular sovereignty-and two American traditions: vigilante justice and constitutional conventions during the nineteenth century. While the traditions may seem unconnected, they are linked by the doctrine of popular sovereignty, which was based on the notion that "the people" are the ultimate and only legitimate basis for government and that "the people" possess the right to reform, alter, or abolish their government at any time. What emerged in the debates over both the proposed California constitution of 1849 and the San Francisco vigilante activities of the 1850 s were conflicting views about both the scope and means whereby the people could exercise this sovereignty.

It is a commonplace that the American legal and constitutional order rests on the idea of a government "of laws and not of men." The phrase implies the primary role that law plays in ordering and maintaining order in American society as well as the close identification of lawyers with that process. It would seem anomalous today to identify members of the legal profession with a vigilante movement that expressly denies the validity of the existing legal system. This reaction is a measure of the distance between our contemporary legal culture and

The author thanks Dean Leo Romero of the University of New Mexico for a summer research grant that made this article possible and Joseph Franaszek, Marlene Keller, and an anonymous PHR referee for their helpful comments on an earlier draft of the paper.

Pacific Historical Review 01993 by the Pacific Coast Branch American Historical Association 
nineteenth-century America. While legal vigilantism seems oxymoronic today, it was not the case in the nineteenth century. The explanation rests on a set of nineteenth-century assumptions common to lawyers and laymen and involves the evolution of how Americans perceived the doctrine of popular sovereignty.

Since the nineteenth-century debates in California over vigilantism and constitution making centered on the source of law-or the operation of processes outside the established legal order-it is particularly revealing to examine the roles and attitudes of members of the legal community towards popular sovereignty. By focusing on lawyers, the degree to which the terms popular sovereignty and vigilantism have shifted in connotation is more easily observed. Lawyers would be more apt to draw on legal or constitutional arguments, if they felt such existed, to justify vigilantism. And lawyers formed a natural occupational link between vigilantism, which a good number of them supported, and the work of nineteenth-century constitutional conventions in which lawyers almost always played a significant if not dominant role.

From popular sovereignty's earliest appearance, its revolutionary potential frightened some people enough to prompt a redefinition of the nature of sovereign power and how it could be exercised within the evolving American republic. Eventually, private power would be constrained by public institutions of justice, and the almost limitless possibilities of constitutional conventions would be restricted by the ability of the people to amend existing constitutions. Ultimately, this limitation on the potential of popular sovereignty kept federal and state constitutional revision within a narrow channel.

At the national level, the revolutionary implications of popular sovereignty were clearly presaged by provisions that appeared in the earliest American state constitutions promulgated in the 1770s. For example, Virginia's bill of rights asserted that "all power is vested in, and consequently derived from, the people; that magistrates are their trustees and servants, and at all times amenable to them," while Delaware's bill of rights provided that "whenever the Ends of Government are perverted, and public Liberty manifestly endangered... [,] the People may, and of Right ought to[,] establish a new, or reform [,] the old 
government."' It took little stretch of the imagination to see in such language the specter of political instability and rapid changes driven by the popular will. Indeed, during the revolutionary struggle itself, Americans had justified the use of mobs and popular uprisings as a legitimate means of resisting the British.2

The use of "extralegal" movements, combined with the constitutional expressions of popular sovereignty, prompted some American leaders in the course of the late eighteenth century to redefine the nature of sovereign power within republican governments. Between the American Revolution and the adoption of the federal Constitution in 1787, thinking about the nature of governments ultimately based on the people's will experienced a significant shift that tended to confine popular sovereignty. ${ }^{3}$ Increasingly, leaders of the revolutionary movement addressed the question of how to balance involving the people in government against maintaining government they regarded as stable, sober, and right thinking. ${ }^{4}$ The more revolutionary

1. William F. Swindler, Sources and Documents of United States Constitutions (11 vols., Dobbs Ferry, N.Y., 1973-1979), II, 198, X, 49. See also Willi Paul Adams, The Finst American Constitutions: Republican Ideology and the Making of the State Constitutions in the Revolutionary Era (Chapel Hill, N.C., 1980), 129-149.

2. Pauline Maier, "Popular Uprisings and Civil Authority in EighteenthCentury America," William and Mary Quarierly, XXVII (1970), 3-35; John Phillip Reid, "In a Defensive Rage: The Uses of the Mob, the Justification in Law, and the Coming of the American Revolution," New Yonk University Law Review XLIX (1974), 1043-1091.

3. For the dimensions of this shift in republican thought, see Gordon S. Wood, The Creation of the American Republic, 1776-1787 (Chapel Hill, N.C., 1969); Daniel Elazar, ed., Republicanism, Representation, and Consent: Views of the Founding Era (New Brunswick, N.J., 1979); Donald S. Lutz, Popular Consent and Popular Control: Whig Political Theory in the Early State Constitutions (Baton Rouge, 1980); Joyce Appleby, "The American Heritage: The Heirs and the Disinherited," Journal of American History, LXXIV (1987), 798-813; Robert F. Williams, "'Experience Must Be Our Only Guide': The State Constitutional Experience of the Framers of the Federal Constitution," Hastings Constitutional Law Quarterly, XV (1988), 403427; and John. R. Vile, "American Views of the Constitutional Amending Process: An Intellectual History of Article V, American Journal of Legal History, XXXV (1991) 44-69. But compare James A. Gardner, "Consent, Legitimacy and Elections: Implementing Popular Sovereignty under the Lockean Constitution," University of Pittsburgh Law Review, LII (1990), esp. 192-213.

4. For such concerns affecting the thought of James Madison between the Revolution and the Constitutional Convention, see Charles F. Hobson, "The Negative on State Laws: James Madison, the Constitution, and the Crisis of Republican Government," William and Mary Quarterly, XXXVI (1979), .215-235. 
ideas articulated in the first state constitutions and generated by the American Revolution did not, however, simply disappear. A political tradition emerged that essentially sought to convert the concept of "the people" from a passive source of constitutionalism into an active role in enforcing and amending the federal constitution. This vision included a state of affairs in which the government and the constitution would be continually reassessed by the people, epitomized by Thomas Jefferson's assertion that the federal constitution belonged only to the living generation. ${ }^{5}$

Ultimately, however, James Madison and other federalists argued successfully for limits to popular sovereignty by confining federal constitutional revision to the cumbersome procedures spelled out in Article Five or to judicial interpretation by the U.S. Supreme Court. In effect, what Madison and others accomplished for the national government was to relegate popular sovereignty to a theory that commanded universal assent while suppressing its actual revolutionary possibilities. The adoption of the Constitution in 1787 and John Marshall's assertion of the power of judicial review in Marbury v. Madison (1803) in large measure achieved the objectives of those who feared, with Madison, the political instability threatened by too much popular control. ${ }^{6}$.Thus, the struggle between these two competing visions of federal constitutional revision was relatively quickly resolved by the early national period.

Nonetheless, the American struggle over the role of "the people" in the context of "altering, reforming or abolishing" their government did not come to an end with the mechanism adopted for constitutional change in the Constitution or by Marshall's assumption of judicial review. The debate instead shifted to the states and was largely conducted within state constitutional conventions during the nineteenth century. Indeed, the continuing debate over the meaning of popular

5. Edmond Cahn, "An American Contribution," in Edmond Cahn, ed., Supreme Court and Supreme Law (Bloomington, 1954), 1-25; Merrill D. Peterson, "Mr. Jefferson's 'Sovereignty of the Living Generation;" Vinginia Quarterly Review, LII (1976), 437-447; Peterson, "Thomas Jefferson, the Founders, and Constitutional Change," in J. Barlow, Leonard Levy, K. Masugi, eds., The American Founding: Esscyss on the Formation of the Constitution (New York, 1988), 275-293.

6. Kermit L. Hall, The Supreme Court and Judicial Review in American History (Washington, D.C., 1985), 1-25; Martury v. Madisom, 5 U.S. 137 (1803). 
sovereignty in state constitutional conventions underscores the connection between vigilantism and constitutional revision. Moreover, the existence of that debate and the ideas it generated gave a legitimacy to proponents of vigilantism that is difficult to appreciate today. If vigilantism represented, in the eyes of its critics, a fearsome source of social disorder, it was equally true that assertions of direct and frequent changes in a constitution by the people represented a similar danger. On the other hand, those who favored a more direct role for the people in constitutional revision-based on a more active or dynamic definition of popular sovereignty-were inclined to acknowledge the justification of vigilantism. In essence, those who opposed vigilantism were quite uncomfortable with the notion that popular sovereignty contained a dimension that placed the right of revolution (and hence a higher authority than the written constitution) in the hands of "the people." By the same token, an overly active resort to the constitutional process of revision threatened to undermine the fundamental nature of constitutional law. This does not mean that those who championed popular sovereignty in state constitutional conventions necessarily favored vigilantism, but that their argument about the nature of popular sovereignty itself gave important theoretical legitimacy to vigilance activities. The issue of the existence of power remained separate from the question of its use.

Eventually it became constitutional orthodoxy to reject any literal attempt to invoke popular sovereignty. ${ }^{7}$ Nonetheless, this position was hardly inevitable or clear in mid-nineteenth-century America. In fact, the debates over vigilantism and constitutional revision reflected a broader struggle over the role of the people in government that would only be resolved after the Civil War.

7. The most dramatic attempt to invoke popular sovereignty was the so-called Dorr Rebellion in Rhode Island in 1842, which has been called "the only revolutionary republican movement that occurred after the Revolution." Harold M. Hyman and William M. Wiecek, Equal justice under Law: Constitutional Development, 1835-1875 (New York, 1982), 3. On the Dorr Rebellion, see George M. Dennison, The Dorr War: Republicanism on Trial. 1831-1861 (Lexington, Ky., 1976); and William M. Wiecek, "A Peculiar Conservatism' and the Dorr Rebellion: Constitutional Clash in Jacksonian America," American Journal of Legal History, XXI (1978), 237-253. 


\section{Popular Sovereignty: Origins and Dynamism}

The American Revolution generated considerable thought about the nature of the right of revolution and the wisdom of various means of political change. The Declaration of Independence had enunciated the right of the people "to alter or to abolish" government "whenever" it became "destructive" of the people's inalienable rights, such as to life, liberty, and the pursuit of happiness. Yet, while articulation of the theoretical right of popular sovereignty remained largely static, what simultaneously happened during the nineteenth century was a redefinition of "the people" and new understandings about the practical implications of their exercise of power. ${ }^{8}$

The theory of popular sovereignty justified the American Revolution and republican government, and established a basic premise in American political life: that political legitimacy ultimately rested with the consent of the people. England's constitutional tradition developed a notion of fundamental law, associated with the ancient heritage of the English common law, implying limits on governmental power. ${ }^{9}$ While fundamental law originated as a means of checking kingly power, eventually constitutional arrangements in England gave Parliament supreme powers. ${ }^{10}$ Even though English political theorists were familiar with the concept of popular sovereignty (in their search for a competing theory to the divine right of kings), it was left to the United States to invent the mechanism of the constitutional convention, the institution that conceptually permitted the exercise of popular sovereignty in the creation of American fundamental law. ${ }^{11}$

Growing tensions between those who held a more conservative view of republicanism and those who believed in majority rule stimulated this rethinking about the governed.

8. Lance Banning, The Jeffersonian Persuasion: Evolution of a Party Idealogy (Ithaca, N.Y., 1978).

9. Wood, Creation of the American Republic, 306-389; J. W. Gough, Fundamental Law in English Constitutional History (Oxford, 1955); J. G. A. Pocock, The Ancient Constitution and the Feudal Law (Cambridge, Eng., 1957).

10. Geoffrey Marshall, Constitutional Theory (Oxford, Eng., 1971), 35-72. The classic treatment of the theory of parliamentary sovereignty remains A. V. Dicey, Introduction to the Study of the Law of the Constitution (10th ed., London, 1959).

11. Edmund S. Morgan, Inventing the People: The Rise of Popular Sovenignty in England and America (New York, 1988), esp. 55-93 and 239-287. 
Indeed, an important division in nineteenth-century American political thought consisted of those who responded to the revolutionary implications of popular sovereignty with greater or lesser ease. This response did not necessarily conform to traditional political party divisions such as those between Whigs and Democrats.

The phrase "popular sovereignty" figured in the debate during the mid-1840s over the issue of slavery in the territories. In the context of that debate, popular sovereignty was used to imply "territorial sovereignty" or the right of the territories to decide whether or not slavery would be permitted within their boundaries. ${ }^{12}$ Indeed, the invocation of popular sovereignty and, later, state sovereignty, in the context of the antebellum debates over slavery, had less to do with the basis of republican government than it did with the question of who exercised what specific power within the federal constitutional structure. To some extent the use of "popular sovereignty" by northern Democrats like Stephen A. Douglas gave the term the added weight it carried, just as the doctrine of state sovereignty would continue to be burdened by its association with the arguments for nullification and secession. Moreover, the association that developed between vigilante action and the doctrine of popular sovereignty tended to discredit "the people" as a legitimate basis of power, even as that doctrine remained the basis of republican institutions. Thus, by the end of the nineteenth-century, a more conservative version of popular sovereignty constrained both the practical political choices and the theoretical basis for action that popular sovereignty had implicitly made possible earlier in the country's history.

As popular government, majoritarianism, and democracy developed political meaning in the course of the nineteenth century, a natural connection emerged with vigilantism. Nineteenth-century citizens, more than those of the twentieth, asserted a closer relationship between the people and their government, including a greater expectation of political accountability and responsiveness. According to historian William C.

12. Arthur Bestor, in a now classic article, made this point in describing the "configurative" role that the federal constitution played in the events leading up to the Civil War. See Bestor, "The American Civil War as a Constitutional Crisis," American Historical Review, LXIX (1964), 327-352. 
Culberson, they "accepted more completely...the concept that government is the servant of the people, subject to their immediate control," and that the people had a "right to shortcut government and overrule officials." 13 Scholars studying violence in America have identified a positive or constructive aspect to nineteenth-century vigilantism: it sought to buttress weak institutions and establish law and order. ${ }^{14}$ In one view, vigilantism was "a communal desire and willingness to enforce existing law or to precipitate a new 'necessary and proper' order by popular rule, in order to meet social exigencies."15

The American practice of using vigilance committees sometimes originated in settings that were not frontiers and that faced crises unrelated to the problem of frontier violence. These early committees, as well as later ones, drew on the long-standing American habit of vigilance: being watchful in regard to the condition of the governed and the welfare of the nation. Such vigilance on the part of the people, implied in American republicanism, underlay the strength of the militia concept of citizen soldiers and the claims to the right to bear arms. Not surprisingly, some of the earliest vigilance committees were composed of leaders of the community. ${ }^{16}$ Only in the 1840 s and 1850 s would the doctrine of citizen vigilance merge with the South Carolina regulator tradition resulting in the association

13. William C. Culberson, Vigilantism: Political History of Private Power in America (New York, 1990), 34.

14. Richard Maxwell Brown, Strain of Violence: Historical Studies of American Violence and Vigilantism (New York, 1975). Brown has located the origin of American vigilantism in the violent activities of the South Carolina Regulators of 1767-1769. This two-year extralegal movement sought to suppress frontier violence in the South Carolina back country and initiated an American tradition. Although eighteenth-century London had its "regulators" and Europe experienced some similar episodes, for Brown the tradition of American vigilantism was "indigenous" since it possessed the unique characteristics of regular (though illegal) organization and existence for a definite (though possibly short) period of time. See Brown, Strain of Violence, 96-98, and Brown, The South Carolina Regulators (Cambridge, Mass., 1963).

15. Culberson, Vigilantism, 11.

16. Ibid., 19; Brown, Strain of Violence, 114. For example, during the War of 1812 , a Virginia Committee of Vigilance organized by the leading men of Richmond and headed by Chief Justice John Marshall had as its purpose the defense of the region from possible British attack. See "The Vigilance Committee: Richmond during the War of 1812," Vinginia Magazine of History and Biognaphy, VII (1899-1900), 225-241. 
of vigilance committees with the control of frontier crime and violence. ${ }^{17}$ Given the prevalence of guns on the frontier, this combination generated a good deal of western vigilantism. But as San Francisco's experience in the 1850s demonstrates, a frontier setting was unnecessary to produce two of the largest vigilance movements in American history.

\section{Popular Sovereignty and State Constitutional Conventions}

Americans in California agitated to establish their own civil government before the end of military hostilities between Mexico and the United States. Many were impatient by the time the American military governor of California, Bennett Riley, called for a constitutional convention in 1849 to establish "a more perfect political organization" and one "fully authorized by law." The convention's president, Robert Semple, also underscored the need for constitutional government by telling the delegates that they were engaged in "the preliminary movement for the organization of a civil government, and the establishment of social institutions. ${ }^{18}$

When Elisha Crosby, lawyer and delegate to the convention, looked back on conditions before the establishment of state government, he contended that

Every man carried his code of laws on his hip and administered it according to his own pleasure. There was no safety of life or property [and] so far as the intervention of law was concerned there was no police. Spanish law was in operation here then and the only way it could he enforced was through the Military Governor and the Prefects and Alcaldes holding office under him. It was an unknown system to our people and we were absolutely in a state of chaos, society was entirely unorganized.... ${ }^{19}$

Crosby's memoirs reflected his desire to establish a familiar government based on common law. His views also captured the

17. Brown, Strain of Violence, 115.

18. William Henry Ellison, A Self-Governing Dominion: Califormia, 1849-1860 (Berkeley, 1950), 1-21; Neal Harlow, California Conquered: War and Peace on the Pacific, 1849-1850 (Berkeley, 1982), 317-337; J. Ross Browne, Report of the Debates in the Convention of California on the Formation of the State Constitution in September and October, 1849 (Washington, D.C., 1850), 5, 18.

19. Elisha Oscar Crosby, Memoirs of Elisha Oscar Crasby: Reminiscences of California and Guatemala from 1849 to 1864, edited by Charles A. Barker (San Marino, 1945), 42. 
unwillingness, if not inability, of Anglo-American lawyers to understand the civil law-based Mexican-California law and legal institutions in operation before they arrived in California. ${ }^{20}$ Failing to comprehend law rooted in a different legal tradition or misinterpreting what they did see, common law-trained lawyers, like Crosby, emphasized the need to create institutions of government and law that were like those in "the states." The Mexican-California system-characterized by a conciliatory, communal, and paternalistic approach to dispute resolution (lacking juries, clear winners and losers, and effective judgments)seemed to them like an absence of justice. They wanted an adversarial, jury-based system that reflected their own concepts of legal certainty and predictability.

Despite the desire for an American-style civil government, some Anglo-Californians had doubts about proceeding without congressional approval. Congress, however, hesitated to upset the delicate balance between free and slave states. Military governor Riley justified the call for a convention on the grounds that since "Congress has failed to organize a new Territorial government, it becomes our imperative duty to take some active measures to provide for the existing wants of the country." The convention was to meet and "frame a State constitution or a Territorial organization, to be submitted to the people for their ratification," and then seek congressional approval. ${ }^{21}$ Riley's plan did not meet with universal favor: San Francisco had already begun to organize a constitutional convention on the grounds that the people had a right to establish a government for their protection. ${ }^{22}$ Eventually, the collective interest in securing a government overcame differences, and Riley's plan formed the basis for the convention that met in Monterey.

As the San Francisco movement suggested, there was broad agreement that the frame of government drew its legitimacy from the people and by implication required popular ratification. Riley's proclamation had called for ratification and the delegates

20. On the inability of Anglo-Americans to understand the indigenous California legal system, see David J. Langum, Law and Community on the Mexican California Frontier: Anglo-American Expatriates and the Clash of Legal Traditions, 1821-1846 (Norman, 1987), 131-152.

21. Browne, Califorria Debates, 3.

22. Ellison, Self-Governing Dominion, 24. 
who assembled in Monterey clearly agreed. Indeed, the principle of popular sovereignty was expressly vindicated, and some proposed provisions for the new constitution came under criticism because they seemed incompatible with that principle. Early in the convention one delegate sought to place a provision in the bill of rights that proclaimed:

As constitutions are the instruments by which the powers of the people are delegated to their representatives, they ought to be construed strictly, and all powers, not expressly granted, should be taken to be reserved. ${ }^{23}$

Other delegates objected that this statement was unnecessary. It mistook the nature of state constitutions in which, by definition, all powers not granted were implicitly reserved to the people. Numerous delegates distinguished between the federal constitution, which represented a finite delegation of power from the sovereign authority of the people, and a state constitution, which represented plenary powers except as expressly limited, or which was, as one delegate put it, a "constitution of restrictions." Another delegate explained that the state legislature, "under the specified restrictions imposed upon it by the people themselves, is a direct emanation from the people."24 Ultimately, the convention rejected the proposed language because it seemed obvious and was already covered in an earlier section of the state bill of rights: "all power is inherent in the people."25 The defeated delegate persisted, and late in the convention introduced a provision with a similar objective, but it was rejected. As one delegate noted, popular sovereignty was "the fundamental principle" of "republican government" and the people "need hardly be reminded that they possess this power." 26

The convention corollary to popular sovereignty was, of course, popular ratification of the constitution before it became fundamental law. This principle was likewise largely assumed by the delegates, although it prompted explicit discussion when some feared that the convention might take actions bypassing

23. Browne, Califormia Debates, 51.

24. Ibid., 52, 53 .

25. Ibid., 52.

26. Ibid., 308-334. 
the people. This occurred when a delegate proposed a resolution seeking the election of a three-person board to draft a code of laws that would be submitted to the legislature at its first session. The proposal triggered a debate over whether the convention had such authority. While many delegates wanted to facilitate the organization of California's government, they shared the reservations expressed by a fellow delegate:

If I understand the directions under which we come here, all our actions must be submitted to the people. I apprehend this resolution is not to go into the Constitution, nor is it to be inserted in the schedule. If so, I think it is clear and positive that it forms no part of our duty, and that we have no right to pass such a resolution.... If we deny that principle, I do not think we have a right to come here at all. ${ }^{27}$

The convention agreed and decided it lacked the power to establish such a committee.

The delegates were clear about their objectives as a constitutional convention even as they inflated their rightful claims for attention. The purpose of a constitution, stated one representative, was to "construct organization and form out of chaos" and "produce a good fundamental system of laws." Another declared that the delegates were " $a$ new people, creating from chaos a government; left free as air to select what is good, from all republican forms of government." The essence of their "most solemn of trusts" was to secure the state's "prosperity and happiness." Their self-conscious charge as constitution-makers was to organize civil government and establish social institutions through fundamental law. "The object of a constitution," as still another delegate put it, was "to impose restrictions on the legislature, to form a state, and to provide a fundamental system of laws within its prescribed limits."28

Given such a momentous mandate, many delegates assumed their work would come under close examination. The "eyes not only of our sister and parent states are upon us, but the eyes of all Europe are now directed toward California," announced the convention president whose words were echoed by a delegate reminding those present that what they accomplished would be

27. Ibid., 301.

28. Ibid., 23, 27, 116, 184. 
subjected to "the scrutiny of all the civilized nations of the earth."29

Though primarily concerned about the creation of the first organic law of a Pacific state, the delegates were also deeply interested in how that fundamental law, if ratified by the people, might be changed. At issue in the debate over the appropriate mechanism was the fear of instability versus a wish for a greater expression of popular sovereignty. The committee on constitutional revision originally proposed that amendments could be submitted to the people after two successive votes of the legislature (the first a simple majority and the second a two-thirds majority). One delegate protested that both votes of the legislature should be by a simple majority. To require otherwise, he argued, would be undemocratic and unrepublican. If a majority of the people were "dissatisfied with their constitution, let them, as they may deem fit, alter and amend it." 30 Many delegates agreed that if a simple majority of the people could create a constitution, a simple majority of them had the right to change the fundamental law.

But other delegates responded that a distinction should be made between how one changed ordinary law (statutes) and fundamental law (a constitution). Statutes, they argued, appropriately reflected "the will of the people" in the legislature to "make and unmake laws," but giving the legislature, which was "the mere transient majority of the people," the power to change the constitution would "greatly militate against the permanent prosperity of the people." The result, they predicted, would be "political excitement" running "wild" that would soon vindicate the need for the two-thirds rule. "[I]n amending the fundamental law of the land," they cautioned, "men should return to their sober second thought" and not put the constitution "at the mercy of the dominant political party of the state." ${ }^{31}$ Despite such protests, the convention dropped the two-thirds voting requirement.

A similar example of the fears and concerns over popular sovereignty occurred in the Maryland constitutional convention

29. Ibid., 18, 141.

30. Ibid., 355.

31. Ibid., 357-358. 
of 1850-1851 that met just before San Francisco organized its first vigilance committee. There is no evidence that the constitution makers in Annapolis or the vigilantes of San Francisco took notice of one another, but both groups wrestled with the issue of legitimate powers and inalienable rights, with one group seeking to constrain and the other seeking to exercise popular sovereignty.

When the Maryland convention began discussing a bill of rights, one delegate proposed language acknowledging that the people "have at all times the inalienable right to alter, reform, or abolish their form of government, in such manner as they may think expedient." This declaration of popular sovereignty stimulated a long and vigorous debate during which delegates asked, as did one conservative Whig, whether "under any sudden impulse...the people might rise and by violence effect a change in the existing government?" After a thoughtful discussion, the convention delegates concluded that the stability and safety inherent in existing governmental structures precluded the need to add any expression to the constitution indicating that "the people" had rights that superseded constitutional procedures. This decision, as one delegate observed, reflected the fear of "any self-constituted body of men choosing to call themselves 'the people,' assuming the power to subvert, when...they please, the whole social and political fabric."32 The additional language that had been suggested was considered inflammatory, but that language not only echoed the Declaration of Independence, but also had been a standard provision in most bills of rights in the first American state constitutions of the eighteenth century..$^{33}$

The debates over the implications of popular sovereignty in California and Maryland, not to mention at other constitutional conventions of the day, raised the question of how to integrate the right of revolution into American constitutional thought and governmental form. Unable to deny the right of revolution as a legitimate and logical extension of popular sovereignty, nineteenth-century constitution-makers differed in how they described that right. The conventions in California and Maryland illustrated the range of positions and thought, and the

32. Debates and Proceedings of the Maryland Reform Convention to Revise the State Constitution (2 vols., Annapolis, 1851), I, 143.

33. Adams, First American Constitutions, 129-149. 
more expansive understandings of popular sovereignty were hardly lost on the leaders and supporters of California's vigilance committees of the 1850 s.

\section{Popular Sovereignty and Vigilantism}

Attitudes toward popular sovereignty did not necessarily dictate reactions to vigilantism. Put another way, not all vigilantes embraced a shared view of popular sovereignty. Still, those who accepted the more expansive aspects of that doctrine were more inclined to support vigilantism because they accepted the underlying rationale for extralegal action, although such a connection was not inevitable. Indeed, most of those who became the leaders of San Francisco's 1856 vigilance committee were conservatives who shied away from the destabilizing implications of popular forces reforming government and only later adopted an expansive theory of popular sovereignty as a justification for vigilantism. ${ }^{34}$ These men-characterized by Josiah Royce as participants in a "Business Man's Revolution"-presented the irony of conservatives invoking constitutional theory to justify revolution. ${ }^{35}$ Their control of the movement convinced them that the right of revolution could be exercised safely. In the mid1850 s, however, those who held a more expansive view of popular sovereignty tended to be the supporters of vigilantism.

This connection between popular sovereignty and vigilantism has been suggested by others, including Lawrence Friedman and Richard Maxwell Brown who have described a tilt in nineteenth-century criminal law toward crime control rather than due process. ${ }^{36}$ Brown, in particular, has argued that lawyers in the late nineteenth and early twentieth century viewed justice

34. On the vigilante movements in San Francisco generally, see Robert M. Senkewicz, Vigilantes in Gold Rush San Francisco (Stanford, Calif., 1985); Kevin J. Mullen, Let Justice Be Done: Crime and Politics in Early San Francisco (Reno, 1989); Mary Floyd Williams, History of the San Francisco Committee of Vigilance of 1851 (Berkeley, 1921); and Hubert H. Bancroft, Popular Tribunals (2 vols., San Francisco, 1887). Senkewicz provides a bibliographical essay on much of the San Francisco vigilance literature. Vigilantes, 203-231.

35. Josiah Royce, California, from the Conquest in 1846 to the Second Vigilance Committee in San Francisco: A Study of American Character (Boston, 1886), 346.

36. Richard Maxwell Brown, "Legal and Behavioral Perspectives on American Vigilantism," in Donald Fleming and Bernard Bailyn, eds., Law in American History (Boston, 1971), 95-144; Lawrence M. Friedman, "State Constitutions and Criminal Justice in the Late Nineteenth Century," Albany Law Review, LIII (1989), 265-281. 
"as a continuum," with one end consisting of "due process legality" and the other of "crime repression extralegality."37 Although lawyers supported the legal system, when it came to criminal activity they were more concerned with eliminating crime than observing due process. Consequently, they could support and even participate in extralegal activities when they felt there were weaknesses in the criminal justice system. For Brown, the legal community's involvement with vigilantism came only after a rational appraisal of the existing system of justice. Popular sovereignty played a role in their decision, he acknowledges, but it did not directly prompt their behavior. Closer examination of the evidence, however, suggests that popular sovereignty, rather than being one of a number of rationales for vigilantism, was the principal rationale for extralegal activities. The reason that many lawyers supported the vigilantes was because such a position found corroboration within the American constitutional tradition.

The constitutional contours of popular sovereignty by the mid-nineteenth century are illustrated in the positive, negative, and ambivalent reactions of lawyers to San Francisco vigilantism. Lawyers who sympathized with the 1851 and 1856 committees emphasized their concerns about the present state of affairs, thereby offering indirect evidence of the theoretical basis of their support for the extralegal activities. The perception of such lawyers formed the basis for action that paralleled the constitutional right to reform or even abolish government when it proved inimical to the public welfare. Lawyers who opposed vigilantism not only denied that the case for revolution had been made but also stressed the destabilizing potential of such popular action. The emphasis on this latter concern echoed worries expressed at nineteenth-century constitutional conventions over the implications of popular sovereignty and constitutional revision. Moreover, opposition to vigilantism also frequently reflected personal conservatism or a sense of duty rather than a rejection of the theoretical principles invoked by the vigilantes.

For some San Francisco lawyers, the presence of courts and government automatically eliminated any justification for the 1851 and 1856 vigilance movements. Moreover, the movements

37. Brown, "Legal and Behavioral Perspectives," 131. 
posed an unacceptable challenge to order and opened the door to the possibility of mob control. If changes in the established order were necessary, they should be achieved within the existing legal framework. To recognize extralegal movements as legitimate was to court revolution by signaling that any group of "the people" could decide when revolutionary power could be exercised.

Those lawyers who sympathized with the vigilance movements accepted the practical consequences of popular sovereignty. For them, the right of popular action was a real option, not just a theory underlying the doctrine of popular sovereignty. If the established institutions in San Francisco were incapable of responding to the needs of the community, then resort to them to bring about changes was a futile and meaningless gesture. Under such circumstances, people's use of extralegal force to accomplish that which the existing government was designed to do, but temporarily unable to achieve, was justified. ${ }^{38}$ For these lawyers, support for the vigilance movements seemed an extraordinary, but entirely defensible, choice, the more so because the movements were animated by public-spirited motives and led by leading members of the community.

Two local observers described to out-of-town correspondents the composition of San Francisco's vigilance committee of 1856 and the attitude of the legal community to that committee. According to William Norris, "most of the members of the bar took the unpopular side of law and order" and were being roundly castigated by the pro-vigilance newspaper, the Bulletin. He claimed objectivity for his assessment on the ground that his sympathies were with the committee, although "not identifying myself with it." A rather different view came from Thomas Larkin, one of the oldest and most successful merchants in California, who wrote a southern California friend: "there is much talk for and against the Committee," but a majority of the merchants were members and "half the best lawyers" supported the vigilantes. ${ }^{39}$ The observers differed about the degree of support from the legal community but agreed that a significant number of lawyers,

38. Ibid., 95-144.

39. William Norris to Montgomery Blair, Jan. 19, 1859, box 5, Blair Family Papers, Library of Congress; Thomas O. Larkin to Abel Stearns, May 31, 1856, box 40, Abel Stearns Papers, Huntington Library. 
covertly if not openly, sympathized with the 1856 committee. Indeed, the personal papers of lawyers who practiced in San Francisco amply bear this out and also indicate that lawyers held pro-vigilante views even before the appearance of San Francisco's first major vigilance committee in 1851 .

\section{Support for Vigilance Activities}

As early as 1849 , a lawyer who became the acknowledged leader of the California bar sided with an extralegal movement to control crime. Hall McAllister became a "captain" in a group created to suppress a criminal element called the "Hounds." 40 After the vigilantes rounded up some of the chief offenders, they convened a meeting of "all the citizens who organized a "court." McAllister served as one of three prosecutors, who tried cases before three judges and a jury. After proceedings that "occupied many days," the defendants were convicted "according to the ordinary legal form." ${ }^{41}$ Although some wished to hang the convicted Hounds, the extralegal group decided to banish them from San Francisco under penalty of death if they returned.

San Francisco's 1851 vigilance committee also found support among the legal community. In August 1851 Henry Haight, a San Francisco lawyer and graduate of Yale who became governor of California in 1867, wrote to his father in Missouri about the recent hangings carried out by the vigilance committee. Like McAllister, Haight emphasized the orderliness of the committee's activities. He also justified its existence because of governmental defects, namely the "inefficiency of the Courts, the imperfections of the laws and the corruption of public officers" that had "rendered the punishment of crime very uncertain and infrequent."42

Other lawyers were even more outspoken in their justification if not support for the vigilantes. John McCrackan wrote

40. For information on McAllister's life and career, see Oscar T. Shuck, History of the Bench and Bar in California (Los Angeles, 1901), 417; and Thomas Gamble, "The McAllisters, 1758-1888," articles printed in the Savannah Morning News, Oct. 5, Nov. 23 and 30, Dec. 14 and 28, 1930, Jan. 4, 11, and 25, 1931, and available in the Bancroft Library.

41. "Statement of Hall McAllister," 15, Vigilance Committee Miscellany, 1877, Bancroft Library.

42. Henry H. Haight to Samuel Haight, Aug. 29, 1851, Henry H. Haight Papers, Huntington Library. 
detailed letters to his family in New Haven, Connecticut, between 1849 and 1853 describing his legal practice in San Francisco and the vagaries of the California justice system. In 1850 in a statement reflecting the city's fear of arson, he asserted: "If a person should be caught firing a building, he would be hung, without the least ceremony...." Nine months later the state of society and the level of crime had become "very bad." ${ }^{43}$ This observation came a month after he had been mugged, an experience that inclined him to see the value of the 1851 committee. That committee, he told his sister Mary, was "composed of our first citizens, and men of wealth and standing." He then cited deficiencies in the punishment of crime, denying that a hanging by the committee was "cold blooded murder" and arguing that "none but the most severe punishment would terrify" the criminal element in the city. ${ }^{44}$ Nonetheless, he acknowledged a tension between his support for the committee and a need to remain aloof from their actions. "[A]s the sworn defender and supporter of the law," he wrote another sister, Lottie, "I am precluded from acting a prominent part in the drama[;] I still I confess to a strong sympathy with the people, and feel inclined to justify their acts." Were he not a lawyer, however, he confessed to feeling "strongly enough to act with the most determined." He regretted that the committee had thus far executed only a minor offender, but even so it had provided a needed "terrible example." A month later he predicted that the "Law and Order" party opposing the vigilance movement would soon "see the folly" in combating "the favorable influence that is now being felt." 45 Indeed, his convictions had now reached the point that when a women's church group created a silk banner in honor of the committee, he and his law partner presented it to a crowd of three hundred vigilantes amid speeches and cheers. "A most happy affair," he recalled, noting as well that such public support of the committee benefitted his law practice, "even in these dull times." 46

The strongest test of the San Francisco legal community's

43. John McCrackan to Lottie McCrackan, May 30, 1850, and Feb. 7, 1851, John McCrackan Papers, Bancroft Library.

44. John McCrackan to Mary McCrackan, June 12, 1851, ibid.

45. McCrackan to Lottie McCrackan, July 10, 1851, ibid.

46. McCrackan to his family, July 29 and Aug. 31, 1851, ibid. 
attitude toward vigilantism came with the events of 1856 . The 1856 committee - the largest and most influential vigilante group in American history-triggered the strongest opposition and generated federal court cases challenging its legitimacy. These trials, involving San Francisco's resident federal judges Matthew McAllister and Ogden Hoffman, best illustrate the tensions and ambivalence lawyers felt about vigilantism. Opponents deliberately sought to involve McAllister and Hoffman as a means of pitting federal authority against the vigilance committee, though in fact, the committee's very existence challenged federal authority.

As in 1851, lawyers who supported the vigilantes stressed the conditions that gave rise to the movement and denied that it had produced anarchy. James Crockett, later to sit on the California supreme court, believed the committee was a response to the "degraded classes" of people who had "caused so much crime and vice." The trials were "conducted with the greatest order and coolness," and he predicted that the vigilantes would "purify the state thoroughly." 47

Crockett soon found himself representing two committee members accused of seizing weapons being transported to the state militia. The trial, he told his wife, was an effort by enemies of the committee to prompt a confrontation with the federal government. Thus far, the vigilantes were acting "with great forbearance," but he predicted "a revolution throughout the State" if the federal government intervened. "Nine tenths of the people will sustain the committee, even though it results in an entire repudiation of the authority of the General government." The "frivolous charges," he declared, were the result of "a few restless and hot-brained men." 48

Despite such bold statements, Crockett harbored the ambivalence common among lawyers who expressed sympathy for the committee. He assured his worried wife that he was not a member of the vigilance committee, but only its legal advocate,

47. Joseph B. Crockett to his wife, May 19, 1856, Joseph Bryant Crockett Papers, Bancroft Library.

48. Crocket to his wife, Sept. 4, 1856, ibid. This episode and the federal prosecution is well documented by John D. Gordan III, Authorized by No Law: The San Francisco Committee of Vigilance of 1856 and the United States Cincuit Court for the Districts of California (Pasadena and San Francisco, 1987). 
and he had advised his clients "to disband at once and restore peace." Still, he conceded that he had not "denounced and abused them, as some others have, because, however much they may have erred, I am satisfied they have acted from honest and upright motives." He described his own behavior as "neutral" and his role that of "a mediator and peacemaker" who was "on the most friendly terms with both sides." Crockett, as had John McCrackan in 1851, experienced the professional advantages of a sympathetic posture toward the committee. When the two committee members whom he was defending were acquitted, he noted that "business has largely increased and we are getting new clients daily, from the moderate and conservative course I have taken." 49 That Crockett could describe his actions as "conservative" reveals much about the range of reactions from other members of the bar.

An even more outspoken supporter of the 1856 vigilance committee belonged to San Francisco's leading law firm, Halleck, Peachy, and Billings. Frederick Billings delivered a speech defending the committee at the funeral of James King of William, the muckraking newspaperman whose murder proved the catalyst for the 1856 uprising. Those who "would call our revolutionary struggle a mob," declared Billings, deserve "the supreme contempt of every honest and high minded man in the state.... We can and do most fully endorse the actions and the measures of the vigilance committee of San Francisco." 50 With a member of one of the most respected legal firms taking such a public stand, it was not surprising that many other lawyers supported the committee, even if only in private. ${ }^{51}$

49. Crockett to his wife, Sept. 4 and 19, 1856, Crockett Papers.

50. Frederick Billings speech on the death of James King of William, p. 10, folder 695, box 7, Halleck, Peachy and Billings Papers, Bancroft Library. Henry Eno, another lawyer and eventual county judge for Calaveras and later Alpine counties, not only strongly supported the committee, but also urged that it take even more drastic action. Henry Eno to William Eno, Oct. 3, 1856, in W. Turrentine Jackson, ed., Twenty Years on the Pacific Slope: Letters of Henry Eno from California and Nevada. 1848-1871 (New Haven, 1965), 125.

51. Lawyers not only supported the vigilante activities in 1856 , but some of them also found the basis for invoking the constitutional right of revolution through the mechanism of the vigilance committee compelling, even after the passage of considerable time. See Annis Merrill, "Statement of Recollections on Early Days of San Francisco" (1878); William R. Wheaton, "Statement of Facts on Early California History" (1878), dictations for the Bancroft Library, Bancroft Library. 
The extent of support for the 1856 committee can be seen in concerns expressed by a special agent for the U.S. Attorney General. Sent to San Francisco by Attorney General Caleb Cushing to deal with Mexican private land claims, the agent arrived as the vigilantes were organizing. Without prompt aid from the federal government, wrote Cushing, "there will not be left the shadow of constitutional authority within the state." Moreover, many federal officials were "giving open encouragement to the mob." ${ }^{2}$ These observations and other complaints led Cushing's successor, Jeremiah S. Black, to remove the local U.S. district attorney for not being aggressive enough in his prosecution of the vigilantes accused of seizing weapons. The removed attorney conceded that he taken a more neutral approach because of a desire to "remove the impression created by the Vigilance Committee that the prosecution originated in angry party spirit and was without a shred of law or reason." ${ }^{53}$

\section{Opposition to Vigilance Activities}

As suggested earlier, those lawyers who opposed the vigilance committees did so out of a deep fear of anarchy. At the same time, however, they frequently expressed sympathy with vigilantes' objectives. William Shaw was one such person. After studying law in Cambridge, Massachusetts, and Ithaca, New York, and then practicing his profession in New York City, he left for California in 1849, serving briefly as a district attorney for San Francisco. Thirty years after the vigilante activities of 1856, he recalled that he had not only refused to join the committee but also "was earnestly and sincerely opposed to it from its start to its ending." Though he acknowledged that his "sympathies were more enlisted with them than I cared to express" and that he admired "the readiness of the people to suppress lawless outrages," he lamented the need to act out of anger. ${ }^{54}$ Lawyer Peter Burnett, California's first civil governor, also recalled his opposi-

52. Lewis Worcester to Caleb Cushing, July 4, 1856, box 9, Correspondence on California Land Claims, Department of Justice, Record Group 60, National Archives, Washington, D.C.

53. William Blanding to Jeremiah S. Black, July 3 and 20, 1857, Attorney General's Letters Received, California, 1846-1870, ibid.

54. William J. Shaw, "Administration of Justice in the Early Days" (1886), 63, dictation for Hubert $\mathrm{H}$. Bancroft, Bancroft Library. 
tion to the 1856 committee on "the ground of principle": the movement was an "incipient rebellion and a fatal precedent." Still, he recognized that "the good people of San Francisco had great reason [not] to be satisfied with the administration of criminal justice."55

Judges, on the other hand, frequently took public stands against the extralegal committees, while privately harboring no approval or admiration for the vigilantes' goals. Their positions were in part a result of their being personally attacked or having the institutions they personified come under perceived dishonor, but what ultimately separated them from their fellow lawyers who privately or publicly supported the vigilantes was their fear that extralegal actions would cause society to break down entirely. In 1851 Ogden Hoffman, the federal district court judge for northern California, joined with several other San Francisco lawyers to wage a vigorous campaign on behalf of "the Supremacy of the Constitution and the Laws of [the] country." 56 His opposition to both the 1851 and 1856 committees derived from his strong commitment to maintaining order through institutions-values he shared in common with other conservative Whigs. During the events of 1856 , a vigilante recalled Hoffman as "one of the most bitter opponents of the Vigilance Committee."57

Hoffman was hardly alone. Among the most strident opponents of the 1856 committee was an associate justice of the California supreme court, David Terry, who described the vigilantes as "a set of $d \_d$ pork-merchants." 58 Equally hostile was Matthew Hall McAllister, a special federal circuit judge for California, who presided over the trial of several 1856 committee members indicted for seizing the arms destined for the state

55. Oscar L. Shafter to his father, April 14, 1856, in Oscar L. Shafter, Life, Diary, and Letters of Oscar L. Shafter, edited by Flora Haines Loughead (San Francisco, 1915), 181; Peter H. Burnett, Recollections and Opinions of an old Pioneer (New York, 1880), 398.

56. San Francisco Alta California, March 6, 1851.

57. Thomas G. Cary, "The Vigilance Committee of San Francisco, 1856," Thomas G. Cary Notebooks, vol. 3, Library of Congress; Daniel Walker Howe, The Political Cullure of the American Whigs (Chicago, 1979), 123-149, 181; Gallagher v. "Yankee," 9 F.Case 1091 (D.C.N.D.Cal. 1859).

58. William Tecumseh Sherman, Memoirs of General William T. Sherman (2 vols., New York, 1875), I, 130. 
militia. Those men were "authorized by no law," declared McAllister. William Tecumseh Sherman, a major-general in the state militia in 1856, shared these sentiments. While not a lawyer, he agreed with those judges appalled by the disrespect for institutions and threat to social stability. As a professionally trained soldier, he saw the movement as undermining his military authority to maintain order. To Sherman the 1856 committee was "an irresponsible organization claiming to be armed with absolute power by the people." It constituted "a personal as well as public threat" by encouraging "anarchy" and "the turbulent tendencies in democratic society." He later recalled that it had the support of "nearly all the best people," but he lamented that vigilantism had become "a fixed institution, and part of the common law of California." For Sherman, this was the ultimate regrettable legacy-one giving "great stimulus" to the "dangerous principle" that "would at any time justify the mob in seizing all the power of government." The principle was especially dangerous because future vigilance committees might "be composed of the worst, instead of the best, elements of a community" 59 Sherman had been prepared to use force to suppress the 1856 committee, but he found himself frustrated by the indecision of superior officers and the unwillingness of Washington to back such resistance with federal troops.

What Sherman, the judges, and other opponents of vigilantism feared most was the danger for extralegal action. Consequently, they sought to limit such action justified by the doctrine of popular sovereignty to the most dire circumstances in which unequivocal evidence existed that inalienable rights of citizens had been usurped. Many, like the future California Supreme Court Justice Oscar Shafter, found it "somewhat difficult to conceive a case where the doctrine of Revolution can have play."60 A similar attitude echoed in Hoffman's opinion in Gallagher v. The "Yankee," a case brought by a victim of the 1856 committee who had been transported to Hawaii. According to Hoffman,

59. Sherman to Henry S. Turner, May 18,1856 , in Dwight L. Clarke, William Tecumseh Sherman: Gold Rush Banker (San Francisco, 1969), 213; Charles Royster, The Destructive War: William Tecumseh Sherman, Stonewall Jackson, and the Americans (New York, 1991), 89, 119120, 137; Sherman, Memoirs, 119, 131.

60. Shafter, Life, Diary, and Letters, 181, 185. 
So long as our country remains under the dominion of law, and so long as the great constitutional provisions which secure the citizen his life, liberty, and his property until deprived of them by due process of law...are prized by the American people, and are enforced by the courts, the deportation of a citizen to a foreign country in an American ship, commanded by an American master, in pursuance or execution of a sentence of an illegal and self-constituted body of men, must remain a marine tort of a most flagrant character. ${ }^{61}$

Similarly, for Judge McAllister, who heard the case on appeal, the critical issue was that the vigilantes were "a body of men authorized by no law, and who substituted their private judgments for the actions of those judicial tribunals to which the constitution and laws of their country had confided solely the distribution of justice." ${ }^{\prime 2}$ This was precisely the point in dispute, for the vigilance committees most certainly rejected the idea that they were "authorized by no law." The principles on which they based their action were the natural right of self defense and especially the right of revolution that underlay the right of the people to reform their government at any time. The delegate who proposed language incorporating this idea into the Maryland constitution would have recognized this argument. So, too, would have most other constitution-makers in the nineteenth century. The real question is whether they would have agreed with the argument as a justification for the steps taken by the San Francisco committees or insisted, with opponents of the committees, that legitimate change could take place within the existing legal system.

This question resonated with the paradox inherent in Luther v. Borden, the United States Supreme Court's response in 1849 to the assertion that popular sovereignty justified the Dorr Rebellion in Rhode Island. ${ }^{63}$ In rejecting that claim-that a group of people, even a majority, could place themselves in opposition to established state government-the court declared that the only remedy for disaffected persons was to work within the constraints of established law. The paradox was that the

61. Gallagher v. "Yankee," 9 F.Case 1091 (D.C.N.D.Cal. 1859).

62. Quoted in Gordan, Authorized by No Law, 29.

63. Luther v. Borden, 48 U.S. 1 (1849). 
existing system precluded the constitutional reforms long sought by Thomas Dorr's followers.

$$
\text { *** }
$$

In the nineteenth century vigilantes and delegates to constitutional conventions shared a desire to reform government. For vigilantes, the goal was less to change the structure of government than to put better people into government. Delegates to constitutional conventions, on the other hand, focused primarily on changing the structure of government. Both groups, however, invoked the same fundamental right to justify their actions: popular sovereignty. In both contexts, the abstract doctrine of popular sovereignty could be formulated in ways and invoked for purposes that frequently made conservatives nervous. Delegates to constitutional conventions, such as those in California and Maryland, as well as the opponents of California vigilantism feared the danger to established order of extralegal activity. Their instincts were conservative in the true sense of the word-inclined to preserve existing institutions. A delegate to Ohio's constitutional convention reveled in the designation. $\mathrm{He}$ went so far as to declare "we are all conservatives," by which he meant that "no man, or any body of men in this country,... [is] willing that the law be violated-while the law exists." ${ }^{4}$ The chief concern of such vigilante opponents as Hoffman, Terry, McAllister, and Sherman was the undermining of existing institutions. The judges stressed the responsibility imposed by their office on maintaining the legal system. As Terry told the members of the 1856 committee: "The difference between my position and yours is...that, being a judicial officer, it is my sworn duty to uphold the law." Sherman, a military officer, felt obligated by "the necessity of putting down this spirit of resistance to the Law:" 65 How Americans-and particularly delegates to state constitutional conventions-felt about the invocation of extralegal means to attain change largely determined the role that popular sovereignty played in American political life. A delegate to California's constitutional convention of 1878-1879 expressed the

64. Report of the Debates and Proceedings of the Convention for the Revision of the Constitution of the State of Ohio (2 vols., Columbus, Oh., 1851), I, 686.

65. Gordan, Authorized by No Law, 33, 46. 
continuing concern over the exercise of popular sovereignty when he described the powers of the convention.

We are representing the people, whose inherent rights are expressed through certain forms, imposed upon themselves by themselves. The people, with all these inherent rights, have found it necessary for their own safety to impose upon themselves rules which they cannot and will not violate....66

Another delegate to this convention reflected the same concern during debate over a provision in the bill of rights specifying the people's right to alter or reform their government. He sought to add the proviso that they could do so "only in accordance with previous established law," explaining that his proposed language sanctioned the right of revolution and thus placed in the constitution "the seeds of its own destruction." 67 His proviso was rejected, but it is revealing of the growing concern with instability that his proposed language was in the 1849 constitution and had provoked no comment during the convention when it was drafted.

Even more revealing of concern was the change incorporated into the 1878-1879 constitution for amending that document. The convention eliminated the old requirement of two successive simple majority votes by the legislature before a proposed amendment would be submitted to the people for ratification. Now, a single legislative vote was required, but it would take a two-thirds majority to approve the amendment. Significantly, when a delegate suggested requiring a simple majority vote, he ran into strong opposition on the grounds that such a change would make the constitution too susceptible to political majorities. Even the outspoken delegate representing the radical Workingman's party worried that "the legislature, by a majority vote, may very frequently submit propositions to the people under a temporary impulse; but if it requires a two-thirds vote, there will be more deliberation and care." 68 Convention

66. Debates and Proceedings of the Constitutional Convention of the State of California, Convened at the City of Sacramento, Saturday, September 28, 1878 (3 vols., Sacramento, 1880-1881), III, 1221 .

67. Ibid., 1167.

68. Ibid., 1277. 
delegates spent less time debating the meaning of popular sovereignty than the procedures for revising the constitution.

By the end of the nineteenth century, the tradition of American vigilantism persisted, but it had lost much of its underlying justification. ${ }^{69}$ Popular sovereignty continued into the twentieth century as an important political idea, but it no longer held the meaning that it did for nineteenth-century Americans. According to historian David Johnson, the demise of San Francisco vigilantism resulted from an acceptance of "the rule of law over the rule of men," a change that helped lead to "the modern state and its mechanisms of social control." ${ }^{\text {"70 }}$ Thus, the process of developing a culture rooted in law inverted Jeffersonian notions of popular sovereignty that people and not forms (even of law) ought to control the direction of government. This more illusive meaning of popular sovereignty that envisioned the people occasionally retaking power into their own handsarticulated in the eighteenth century and enjoying a lively and legitimate life in state constitutional debates in the nineteenth century-is easily overlooked given the significance that the rule of law has today. To fully understand the American concept of popular rule, it is necessary to recapture the lost and very rich world of nineteenth-century state constitutionalism.

69. Brown, Strain of Violence, 144-179.

70. David A. Johnson, "Vigilance and the Law: The Moral Authority of Popular Justice in the Far West," American Quarterly XXXIII (1981), 562. 
